\title{
Implikasi manajemen stres dan dukungan sosial terhadap kualitas hidup lansia
}

\author{
Mutia Putri Galuha,1, Alfi Purnamasarib,2* \\ a,bFakultas Psikologi, Universitas Ahmad Dahlan, Yogyakarta \\ 1'mutiaptr@gmail.com; *2alfi_purnamasari@yahoo.com \\ *Correspondent Author
}

KATAKUNCI ABSTRAK

dukungan sosial;

kualitas hidup;

manajemen stres

\section{KEYWORDS}

stress management; social support; quality of life
Penelitian ini dilatarbelakangi oleh minimnya perhatian dari masyarakat tentang kualitas hidup lansia, sementara kualitas hidup merupakan salah satu aspek penting dari kehidupan manusia, termasuk lansia. Oleh karena itu, penelitian ini bertujuan untuk mengetahui hubungan antara manajemen stres dan dukungan sosial dengan kualitas hidup pada lanjut usia. Metode yang digunakan pada penelitian ini adalah metode kuantitatif. Sampel penelitian adalah 80 orang lanjut usia yang tinggal di Kelurahan Sindangkasih, Kabupaten Majalengka, Jawa Barat yang dipilih dengan menggunakan purposive sampling. Alat ukur yang digunakan berupa kuesioner WHOQOL-BREF, skala manajemen stres dan skala dukungan sosial. Data dianalisis dengan menggunakan teknik analisis regresi berganda. Hasil dan kesimpulan penelitian menunjukan bahwa ada hubungan yang sangat signifikan antara manajemen stres dan dukungan sosial dengan kualitas hidup lansia. Selanjutnya, ada hubungan positif yang sangat signifikan antara manajemen stres dengan kualitas hidup lansia, namun tidak ada hubungan antara dukungan sosial dengan kualitas hidup lansia.

\section{Implications of stress management and social support on the quality of life of the elderly}

This research is motivated by the lack of attention from the public about the quality of life of the elderly, while the quality of life is one of the important aspects of human life, including the elderly. Therefore, this study aims to determine the relationship between stress management and social support with quality of life in the elderly. The method used in this research is a quantitative approach. The research sample was 80 elderly people living in Sindangkasih Village, Majalengka Regency, West Java who were selected using purposive sampling. The measuring instruments used are WHOQOL-BREF questionnaire, stress management scale and social support scale. The data were analyzed using multiple regression analysis techniques. The results and conclusions of the study indicate that there is a very significant relationship between stress management and social support with the quality of life of the elderly. Furthermore, there is a very significant positive relationship between stress management and the quality of life of the elderly, but there is no relationship between social support and the quality of life of the elderly. 


\section{Pendahuluan}

Lanjut usia atau yang biasa dikenal dengan istilah lansia merupakan suatu fase kehidupan terakhir dalam proses perkembangan manusia Lanjut usia adalah periode penutup dalam rentang hidup seseorang, yaitu suatu periode dimana individu telah beranjak dari periode terdahulu yang lebih menyenangkan atau beranjak dari waktu yang penuh dengan manfaat (Hurlock, 2013). Usia enampuluhan biasanya dipandang sebagai garis pemisah antara usia madya dan usia lanjut sehingga individu yang berusia enam puluh tahun umumnya digolongkan sebagai lanjut usia (Hurlock, 2013). Peraturan Pemerintah Republik Indonesia Nomor 34 Tahun 2004 juga menyatakan bahwa lanjut usia adalah seseorang yang telah mencapai usia 60 tahun ke atas (Kementrian Kesehatan RI, 2017).

Berbicara tentang lanjut usia, menurut data terakhir yang diambil oleh United Nations Departement of Economic and Social Affair Population Division (2017) jumlah penduduk lanjut usia di dunia pada tahun 2015 sebanyak 12,3\%, dan diperkirakan pada tahun 2020 meningkat menjadi $13,5 \%$. Berdasarkan data proyeksi penduduk diperkirakan pada tahun 2017 terdapat 23,66 juta jiwa (9,03\%) penduduk lanjut usia di Indonesia. Diprediksi jumlah peduduk lanjut usia pada tahun 2020 akan mencapai 27,08 juta. Pada tahun 2017 Indonesia termasuk negara dengan struktur penduduk menuju tua karena mempunyai populasi lanjut usia di atas tujuh persen (Kementrian Kesehatan RI, 2017). Jumlah lanjut usia yang meningkat menunjukkan bahwa pemerintah sudah lebih tanggap terhadap masalah-masalah yang dihadapi oleh lanjut usia, dengan kata lain kesejahteraan lanjut usia sudah terjamin. Lanjut usia yang sejahtera mengindikasikan kualitas hidup yang tinggi namun taraf kualitas hidup yang tinggi belum merata di setiap daerah.

Berdasarkan Surat Keputusan Walikota Yogyakarta Nomor 450 Tahun 2019 Tentang Roadmap Kota Yogyakarta Menuju Kota Ramah Lanjut Usia (2019) masalah yang berkaitan dengan kelompok lanjut usia di Indonesia mengalami peningkatan. Permasalahan yang muncul pada lanjut usia adalah kurangnya apresiasi, sehingga tidak jarang para lanjut usia terlantar meskipun memiliki keluarga. Selain itu, permasalahan lain yang muncul adalah proses penuaan mengakibatkan lanjut usia mengalami penurunan kemampuan fisik dan kognitif, kemampuan panca indera terhadap daya tangkap visual, memori, kepekaan pendengaran dan ketajaman penciuman menurun secara gradual. Lanjut usia juga banyak yang mengalami penyakit pada berbagai organ. Kombinasi perubahan alamiah dan penyakit yang dialami membuat lansia merupakan populasi manusia yang rentan apabila tidak diperhatikan. Lanjut usia biasanya sudah mengalami penurunan kualitas dalam aspek fisik, psikologis, dan kognitif (BKKBN, 2013). Banyak permasalahan yang akan dihadapi oleh lanjut usia seperti penurunan fungsi fisik dan perubahan-perubahan lain yang akan terjadi selama menjadi seorang yang berusia lanjut. Jika lanjut usia tidak memiliki kontrol atas dirinya dan juga tidak mendapatkan dukungan dari keluarga, lingkungan dan pemerintah dalam menghadapi permasalahan-permasalahan tersebut maka akan berdampak pada kualitas hidup lanjut usia.

Kualitas hidup erat kaitannya dengan kesejahteraan lanjut usia yang dijelaskan dalam Undang-undang Republik Indonesia Nomor 13 Tahun 1998 tentang Kesejahteraan Lanjut Usia yaitu suatu tata kehidupan dan penghidupan sosial baik material maupun spiritual yang 
diliputi oleh rasa keselamatan, kesusilaan, dan ketentraman lahir batin yang memungkinkan bagi setiap warga negara untuk mengadakan pemenuhan kebutuhan jasmani, rohani, dan sosial sebaik-baiknya bagi diri, keluarga, serta masyarakat dengan menjunjung tinggi hak dan kewajiban asasi manusia sesuai dengan Pancasila (Undang-Undang Republik Indonesia, 1998).

World Health Organization Quality of Life (WHOQOL) (1998) mendefinisikan kualitas hidup sebagai persepsi yang dimiliki oleh individu tentang kepuasan terhadap situasi kehidupan yang dipengaruhi oleh kebudayaan dan sistem nilai yang diterapkan di tempat individu tersebut tinggal dan berkaitan dengan tujuan, harapan serta kepedulian dari individu tersebut. Kualitas hidup menurut Bowling (Vaarama, Pieper, \& Sixsmith, 2008) adalah konsep yang mencakup aspek sosial, psikologis, dan domain fisik kehidupan, menggabungkan penilaian subjektif dari domain kehidupan yang penting untuk mencapai kepuasan. Kualitas hidup merupakan penilaian yang dipengaruhi oleh individu dari aspek fisik dan psikologis serta pengaruh dari sistem sosial, ekonomi, dan lingkungan individu, yang artinya penilaian kualitas hidup mencakup dua hal yaitu penilain secara subjektif dan objektif.

The WHOQOL Group (1998) membagi kualitas hidup menjadi empat domain kualitas yaitu kesehatan fisik, psikologis, hubungan sosial dan lingkungan. Domain kesehatan fisik secara garis besar berkaitan dengan aspek-aspek yang berhubungan dengan kesehatan fisik yang terdiri dari: rasa sakit dan ketidaknyamanan, tenaga dan kelelahan, tidur dan istirahat, mobilitas, aktivitas, pengobatan dan pekerjaan. Domain psikologis merupakan domaindomain yang terkait dengan kondisi psikologis seseorang yang mempengaruhi kualitas hidupnya yang terdiri dari: 1) perasaan positif, 2) berpikir, belajar, ingatan, dan konsentrasi, 3) harga diri, 4) citra tubuh dan penampilan, 5) Perasaan negatif dan 6) kerohanian. Selanjutnya domain hubungan sosial terdiri dari: 1) hubungan pribadi, 2) dukungan sosial dan 3) aktivitas seksual. Sementara domain lingkungan terdiri dari: 1) keselamatan dan keamanan fisik, 2) lingkungan rumah, 3) sumber keuangan, 4) kesehatan dan kepedulian sosial (ketersediaan dan kualitas), 5) kesempatan untuk mendapatkan informasi baru dan keterampilan, 6) partisipasi dan kesempatan untuk rekreasi dan liburan, 7) lingkungan fisik (polusi/kebisingan/lalu lintas/iklim), serta 8) transportasi.

Dampak dari kualitas hidup yang rendah pada lanjut usia adalah mudah merasa stres, merasa dirinya tidak lagi berguna bagi masyarakat, serta tingkat ketergantungan pada orang lain menjadi sangat tinggi (Kementrian Kesehatan RI, 2016). Stres yang berlarut-larut dalam intensitas yang tinggi dapat menyebabkan munculnya penyakit fisik dan mental pada lanjut usia yang akhirnya dapat menurunkan produktivitas dan buruknya hubungan interpersonal (Rasmun, 2004). Oleh karena itu, mengidentifikasi berbagai stres dan pola coping merupakan hal yang penting bagi lanjut usia dikarenakan berbagai pemicu stres yang unik akan dihadapi oleh lanjut usia (Boyd \& Nihart, 2005). Tidak hanya itu saja, bahwa kemampuan untuk mengontrol stres secara efektif dan mampu mengendalikan berbagai stres yang dirasakan merupakan faktor kunci dalam promosi kesehatan mental yang baik (Gatz, Kasl-Godley, \& Karel, 1996).

Adapun faktor-faktor yang mempengaruhi kualitas hidup menurut Raeburn dan Rootman (1988) diantaranya kontrol, kesempatan yang potensial, sistem dukungan, keterampilan, kejadian dalam hidup, sumber daya, perubahan lingkungan dan perubahan politik. Berdasarkan beberapa faktor tersebut, peneliti lebih memfokuskan pada faktor kontrol dan sistem dukungan. Faktor kontrol berkaitan dengan pembatasan perilaku atau kegiatan yang dilakukan untuk menjaga kondisi tubuh, dalam hal ini adalah manajemen stres. Selain itu, penelitian ini juga ingin mengungkap tentang sistem dukungan berupa dukungan sosial.

Banyaknya perubahan yang harus dihadapi oleh lanjut usia tentunya membutuhkan kontrol dari dalam diri sendiri berupa manajemen stres yang baik karena menjadi lanjut usia merupakan transisi besar dalam kehidupan manusia dengan banyak perubahan dan 
penyesuaian. Lanjut usia yang memiliki manajemen stres yang baik diharapkan akan memiliki kualitas hidup yang baik pula. Manajemen stres merupakan suatu keterampilan yang memungkinkan seseorang untuk mengantisipasi, mencegah, mengelola, dan memulihkan diri dari stres yang dirasakan karena adanya ancaman dan ketidakmampuan dalam coping yang dilakukan (Smith, 2002). Menurut hasil penelitian yang dilakukan oleh Sari dan Yuslia (2013) individu yang memiliki manajemen stres yang baik akan memiliki kualitas hidup yang baik, dan sebaliknya individu yang memiliki manajemen stres kurang baik akan berimbas pada menurunnya kualitas hidup.

Indikator manajemen stres menurut Robbins dan Coulter (2004) terdiri dari identifikasi gejala stres, analisis gejala stres, strategi terhindar dari stres dan coping stres. Identifikasi gejala stres merupakan suatu tindakan yang bertujuan untuk menentukan sumber stres yang keadaannya lebih menetap. Analisis gejala stres merupakan suatu proses untuk mendapatkan sebuah informasi berupa tanda-tanda dari sikap dan perasaan yang diperlihatkan akibat stres yang dapat diinterpretasikan. Strategi terhindar dari stres merupakan suatu strategi kognitif dan perilaku dinamis yang berfokus pada suatu tindakan yang diarahkan kepada pemecahan masalah.

Faktor lain yang diduga berpengaruh terhadap kualitas hidup adalah dukungan sosial. Penurunan fungsi di segala aspek perkembangan memberikan dampak sehingga lanjut usia harus mendapat prioritas utama dalam penanganannya agar dapat tetap menjalankan fungsi serta kebutuhan jasmani dan rohaninya dapat tetap terpenuhi. Oleh karena itu, lanjut usia sangat memerlukan dukungan sosial dalam kehidupannya. Menurut Feeney dan Collins (2015) dukungan sosial merupakan proses interpersonal yang berfungsi untuk mendorong upaya individu dalam pertumbuhan diri maupun adaptasi di situasi sulit. Uchino (2004) menyebutkan bahwa dukungan sosial mengacu pada kenyamanan, perhatian, penghargaan atau bantuan yang tersedia bagi seseorang dari orang atau kelompok lain. Dukungan sosial di masa lanjut usia sangat diperlukan, karena dapat memberikan pengaruh pada kualitas hidup lanjut usia secara umum, baik dari sisi kesehatan fisik maupun psikologis (Chang, Wray \& Lin, 2014). Menurut Berk (2017), selama konteks sosial dan budaya memberikan orang lanjut usia dukungan, penghargaan, dan arah hidup, maka masa usia lanjut dapat menjadi masa keberlanjutan potensi pada lanjut usia.

Menurut Sarafino (2011) dukungan sosial dapat diperoleh dari banyak sumber seperti pasangan, keluarga, teman, dokter atau organisasi. Menurut penelitian yang dilakukan oleh Tamara, Bayhakki, dan Nauli (2014) dukungan keluarga mampu meningkatkan kualitas hidup bagi lanjut usia penderita diabetes karena dukungan keluarga diberikan dalam bentuk dukungan emosional, instrumental, penghargaan dan informasi yang mampu memberikan rasa nyaman. Lajut usia yang ada di Indonesia tidak semuanya tinggal bersama dengan keluarganya, namun sebagian tinggal di panti. Hasil penelitian yang dilakukan Putri, Fitriana, Ningrum dan Sulastri (2015) menunjukan adanya perbedaan dalam kualitas hidup pada lanjut usia yang tinggal di panti dan lanjut usia yang tinggal bersama keluarganya. Lanjut usia yang tinggal di panti memiliki kualitas hidup yang lebih rendah jika dibandingkan dengan yang tinggal bersama dengan keluarga.

Sarafino (2011) menyatakan bahwa dukungan sosial terdiri dari aspek dukungan emosional, dukungan penghargaan, dukungan instrumental dan dukungan informatif. Dukungan emosional melibatkan ekspresi rasa empati dan perhatian terhadap individu, sehingga individu tersebut merasa nyaman, dicintai dan diperhatikan. Dukungan penghargaan melibatkan ekspresi yang berupa pernyataan setuju dan penilaian positif terhadap ide-ide, perasaan dan peforma orang lain. Dukungan instrumental melibatkan bantuan langsung, penyediaan sarana untuk mempermudah menolong orang lain, meliputi peralatan, perlengkapan, dan sarana pendukung yang lain termasuk di dalamnya memberikan peluang waktu. Dukungan informatif meliputi pemberian informasi untuk 
mengatasi masalah pribadi yang terdiri atas pemberian saran, nasehat, pengarahan dan umpan balik tentang bagaimana memecahkan persoalan.

Berdasarkan uraian di atas, penelitian ini bertujuan untuk menguji hubungan antara manajemen stres dan dukungan sosial dengan kualitas hidup pada lanjut usia. Hasil penelitian ini diharapkan mampu memberikan informasi tentang peranan dari manajemen stres dan dukungan sosial terhadap peningkatan kualitas hidup lansia yang selama ini sangat jarang diteliti. Hipotesis mayor pada penelitian ini adalah ada hubungan antara manajemen stres dan dukungan sosial dengan kualitas hidup pada lanjut usia. Hipotesis minor pada penelitian ini yaitu 1) ada hubungan positif antara manajemen stres dengan kualitas hidup lanjut usia, serta 2) ada hubungan positif antara dukungan sosial dengan kualitas hidup lanjut usia.

\section{Metode}

Metode yang digunakan pada penelitian ini adalah metode kuantitatif. Populasi pada penelitian ini memiliki kriteria; individu yang berusia 60 tahun ke atas, bertempat tinggal di Kelurahan Sindangkasih, Kabupaten Majalengka dan mampu berkomunikasi dengan baik. Teknik sampling yang digunakan adalah purposive sampling. Penelitian ini melibatkan 80 orang sampel yang terdiri dari 48 orang (60\%) lanjut usia wanita dan 32 orang (40\%) orang lanjut usia laki-laki. Sebanyak 44 orang (55\%) dari sampel penelitian berusia 60-64 tahun, 20 orang (25\%) berusia 65-69 tahun serta 16 orang (20\%) berusia di atas 70 tahun. Jika ditinjau dari tingkat pendidikan sebanyak 77 orang $(96,25 \%)$ memiliki tingkat pendidikan Sekolah Dasar (SD) dan 3 orang (3,75 \%) memiliki tingkat pendidikan Sekolah Menengah Pertama (SMP).

Alat ukur yang digunakan dalam penelitian menggunakan kuesioner WHOQOL-BREF, skala manajemen stres dan skala dukungan sosial. Pengukuran variabel manajemen stres menggunakan skala manajemen stres yang dibuat oleh peneliti berdasarkan indikator manajemen stres yang dikemukakan oleh Robbins dan Coulter (2004) berjumlah 28 aitem. Pengukuran dukungan sosial menggunakan skala dukungan sosial yang dibuat oleh peneliti berdasarkan aspek dukungan sosial yang dikemukakan oleh Sarafino (2011) berjumlah 56 aitem. Kuesioner WHOQOL-BREF merupakan pengembangan dari alat ukur WHOQOL-100. Kedua alat ukur ini dibuat oleh tim dari World Health Organization (WHO) yang berjumlah 26 aitem terdiri dari dua aitem pertanyaan umum, tiga aitem unfavorabel dan 21 aitem favorabel. Kuesioner WHOQOL-BREF terdiri dari empat domain yaitu kesehatan fisik, psikologis, hubungan sosial dan lingkungan.

Uji coba alat ukur melibatkan 60 orang sampel yang memiliki karakteristik sama dengan populasi penelitian. Hasil analisis aitem pada skala manajemen stres menghasilkan 24 aitem dengan indeks daya beda aitem terendah sebesar 0,312 dan tertinggi 0,592, serta koefisien reliabilitas Alpha sebesar 0,823. Hasil analisis aitem pada skala dukungan sosial menghasilkan 28 aitem dengan indeks daya beda terendah sebesar 0,346 dan tertinggi 0,799, serta koefisien reliabilitas Alpha sebesar 0,913. Hasil analisis aitem dalam Kuesioner WHOQOL-BREF menghasilkan 23 aitem dengan indeks daya beda terendah sebesar 0,259 dan tertinggi 0,756, serta koefisien reliabilitas Alpha sebesar 0,878.

Teknik analisis data yang digunakan dalam penelitian adalah analisis regresi berganda. Sebelum dilakukan analisis dengan menggunakan analisis regresi berganda, terlebih dahulu dilakukan uji asumsi yang meliputi uji normalitas, uji linieritas, dan uji multikolinieritas.

\section{Hasil}

Berdasarkan hasil uji normalitas, dapat diketahui bahwa variabel manajemen stres memiliki nilai $p$ sebesar $0,500(p>0,05)$, variabel dukungan sosial memiliki nilai $p$ sebesar $0,570(p>0,05)$, serta variabel kualitas hidup memiliki nilai p sebesar 0,312 ( $p>0,05)$. Dengan demikian, dapat disimpulkan bahwa variabel kualitas hidup, dukungan sosial dan manajemen 
stres memiliki sebaran yang normal. Hasil pengujian linieritas antara variabel manajemen stres dan kualitas hidup menunjukkan taraf signifikansi p (linearity) sebesar 0,000 $(\mathrm{p}<0,05)$ dan taraf signifikansi $\mathrm{p}$ (deviation from linearity) sebesar $0,538(\mathrm{p}>0,05)$ yang berarti bahwa data bersifat linier. Sedangkan antara variabel dukungan sosial dan kualitas hidup menunjukkan taraf signifikansi $\mathrm{p}$ (linearity) sebesar $0,042(\mathrm{p}<0,05)$ dan taraf signifikansi $\mathrm{p}$ (deviation from linearity) sebesar $0,155(p>0,05)$ yang berarti data juga bersifat linier. Berikutnya, hasil uji multikolinieritas antara variabel manajemen stres dan dukungan sosial menunjukkan nilai VIF (Variance Inflation Factor) sebesar 1,252 (VIF $<10)$ dan nilai tolerance sebesar $0,799(>0,1)$ sehingga dapat disimpulkan bahwa tidak terjadi multikolinearitas.

Hasil analisis data dengan menggunakan analisis regresi berganda menunjukkan besarnya koefisien regresi $R=0,543, F=16,123$ dengan koefisien determinan $\left(R^{2}\right)$ sebesar 0,295 ; dan taraf signifikansi sebesar $\mathrm{p}=0,000(\mathrm{p}<0,01)$. Berdasarkan hasil analisis tersebut dapat disimpulkan bahwa terdapat korelasi yang sangat signifikan antara manajemen stres dan dukungan sosial dengan kualitas hidup (hipotesa diterima). Sumbangan efektif (SE) dari manajemen stres dan dukungan sosial terhadap kualitas hidup adalah sebesar 29,5\%.

Hasil uji hipotesis minor yang pertama menunjukkan skor zero order ( $\mathrm{r}$ ) sebesar 0,542 dengan nilai $\mathrm{p}=0,000 \quad(\mathrm{p}<0,01)$ sehingga mengindikasikan bahwa ada hubungan yang siginifikan antara manajemen stres dengan kualitas hidup (hipotesa diterima). Hasil uji hipotesis minor yang kedua menunjukkan skor zero order (r) sebesar 0,215 dengan nilai $p=0,744(p>0,01)$ sehingga mengindikasikan bahwa tidak ada hubungan antara dukungan sosial dengan kualitas hidup (hipotesa ditolak). Hasil uji hipotesis minor dapat dilihat pada Tabel 1.

Tabel 1.

Hasil Uji Hipotesis Minor

\begin{tabular}{lll} 
Variabel & $\boldsymbol{r}$ & $\boldsymbol{p}$ \\
\hline Manajemen stres * kualitas hidup & 0,542 & 0,000 \\
Dukungan sosial* kualitas hidup & 0,215 & 0,744 \\
\hline
\end{tabular}

Sumber: Data primer.

Kategorisasi data penelitian dibuat berdasarkan skor hipotetik dan dapat dilihat pada Tabel 2 berikut.

Tabel 2.

Kategorisasi Manajemen Stres, Dukungan Sosial, dan Kualitas Hidup

\begin{tabular}{llll}
\hline Kategori & Manajemen stres & Dukungan Sosial & Kualitas Hidup \\
\hline Tinggi & $38,7 \%$ & $40 \%$ & $17,5 \%$ \\
Sedang & $61,25 \%$ & $60 \%$ & $80 \%$ \\
Rendah & $0 \%$ & $0 \%$ & $2,5 \%$ \\
\hline
\end{tabular}

Kategorisasi berdasarkan mean hipotetik menunjukkan bahwa sebagian besar sampel penelitian memiliki manajemen stres, dukungan sosial dan kualitas hidup dalam kategori sedang.

\section{Pembahasan}

Hasil penelitian menunjukkan bahwa terdapat hubungan antara manajemen stres dan dukungan sosial dengan kualitas hidup pada lanjut usia. Lanjut usia yang memiliki kemampuan manajemen stres yang baik dan mendapatkan dukungan sosial yang tinggi maka akan memiliki kualitas hidup yang baik pula. The WHOQOL Group (1998) membagi kualitas 
hidup menjadi empat domain kualitas yaitu kesehatan fisik, psikologis, hubungan sosial dan lingkungan. Manajemen stres menurut Robbins dan Coulter (2004) memiliki empat indikator yaitu identifikasi gejala stres, analisis gejala stres, strategi terhindar dari stres dan koping stres. Lansia yang mampu mengidentifikasi gejala-gejala stres akan lebih mampu untuk menghindar dari keadaan stres sehingga tidak akan berada dalam fase stres yang terlalu lama. Hal tersebut berdampak pada salah satu domain kualitas hidup yaitu domain psikologis. Lanjut usia yang mampu mengidentifikasi gejala stres juga akan terhindar dari perasaan negatif seperti cepat merasa putus asa, cemas berlebihan, dan merasakan sedikitnya kesenangan dalam hidup. Sebaliknya, lanjut usia akan lebih menunjukan perasaan positif seperti keseimbangan dalam mengendalikan emosi, lebih menghargai keadaan dirinya, dan menikmati sesuatu yang baik dalam kehidupan. Selain itu, stres tidak hanya mempengaruhi faktor psikologis tetapi mempengaruhi kesehatan fisik juga. Lansia yang mengalami stres maka kondisi fisiknya dapat melemah sehingga merasa cepat lelah, begitupula kecepatan reaksi akan menurun sehingga menyebabkan gerakan menjadi lamban. Selanjutnya, lansia yang mengalami stress juga menjadi rentan terhadap berbagai macam penyakit seperti nyeri sendi dan otot, sulit berkonsentrasi, hingga sulit tidur. Dengan demikian, lansia yang mampu mengidentifikasi gejala stres diharapkan akan mampu menurunkan tingkat stresnya, sehingga tidak menambah parah keadaan fisik serta mengancam kesehatan yang mana akan berdampak pada menurunnya kualitas hidup lansia.

Indikator lain dari manajemen stres adalah analisis terhadap gejala stres. Analisis gejala stres dilakukan untuk mengetahui secara spesifik hal atau peristiwa apa yang membuat lanjut usia tersebut merasakan stres. Analisis gejala stres akan berpengaruh terhadap domain psikologis pada kualitas hidup. Lanjut usia yang mampu menganalisis gejala stres diharapkan dapat terhindar dari perasaan-perasaan negatif yang mampu menimbulkan stres sehingga tidak terlalu lama berada dalam kondisi tertekan. Stres yang berlarut-larut, dan dalam intensitas yang tinggi dapat menyebabkan penyakit mental dan fisik yang pada akhirnya dapat menurunkan produktivitas dan buruknya hubungan interpersonal. Selain itu, lanjut usia yang kurang mampu menganalisis gejala stress yang dimiliki akan mempengaruhi peforma dirinya sehingga menjadi cepat lelah, tidur menjadi tidak berkualitas yang menyebabkan mudahnya merasa sakit kepala atau mengalami psikosomatis. Selain itu, gejala lainnya adalah menurunnya motivasi untuk melakukan aktivitas sehari-hari yang berpengaruh pada hubungan sosial. Jika kondisi tersebut sering terjadi dan berlangsung dalam jangka waktu yang lama, maka lanjut usia tersebut akan memiliki kualitas hidup yang kurang baik.

Indikator lain dari manajemen stres adalah strategi terhindar dari stress yang merupakan suatu strategi kognitif dan perilaku dinamis yang berfokus pada suatu tindakan yang diarahkan kepada pemecahan masalah. Lanjut usia merencanakan kegiatan atau perilaku yang diharapkan dapat memecahkan permasalahan yang sedang dihadapi sehingga permasalahan tersebut tidak bertambah berat atau menimbukan perasaan yang semakin menekan. Selain itu strategi terhindar dari stres dapat berpengaruh pada munculnya perasaan positif sehingga lanjut usia mampu melihat peluang dalam menyelesaikan masalah yang membuatnya tertekan. Lanjut usia juga akan terhindar dari perasaan negatif karena memahami bahwa setiap masalah memiliki jalan keluar, sehingga lansia akan bertindak untuk menyelesaikan permasalahan. Strategi terhindar dari stres juga akan berpengaruh terhadap domain fisik karena lanjut usia yang memiliki strategi terhindar dari stres yang baik akan mengetahui keadaan fisik, dan apa saja yang dibutuhkan oleh tubuhnya agar tetap berfungsi dengan baik. Strategi terhindar dari stres juga mempengaruhi domain hubungan sosial dalam kualitas hidup karena lanjut usia tidak selamanya dapat bertindak sendirian untuk menyelesaikan masalah yang dihadapi sehingga membutuhkan dukungan dari orangorang di sekitarnya.

Indikator lain dari manajemen stres adalah coping stress. Coping stress adalah perilaku atau tindakan yang dilakukan untuk mengurangi atau menghilangkan stres. Coping stress 
akan mempengaruhi domain psikologis dalam kualitas hidup karena lanjut usia akan melakukan coping stress untuk mengurangi ketegangan psikologis dalam kondisi yang penuh tekanan dengan cara mengembangkan kontrol diri dan berpikir positif. Lanjut usia yang memiliki perasaan yang positif diharapkan memiliki kualitas hidup yang baik serta dapat pula mendekatkan diri kepada Tuhan atau melakukan aktivitas spiritual. Aktivitas fisik seperti berolahraga ringan atau senam lansia juga dapat menjadi coping stress yang baik, karena dengan aktivitas fisik yang tepat maka lanjut usia akan mampu mengurangi stres yang dirasakan sehingga mempengaruhi domain kesehatan fisik dalam kualitas hidup.

Hasil penelitian menunjukkan bahwa sebagian besar lanjut usia yang menjadi sampel penelitian, yaitu sebanyak $61,25 \%$ memiliki manajemen stres dalam kategori sedang. Hal tersebut menunjukkan bahwa sebagian besar lanjut usia yang menjadi sampel penelitian memiliki kemampuan yang cukup baik dalam mengantisipasi, mencegah, mengelola, dan memulihkan diri dari stres yang dirasakan. Kemampuan yang cukup baik para lansia pada penelitian ini menunjukkan hasil yang sejalan dengan penelitian yang dilakukan oleh Sari dan Yuslia (2013), yaitu terdapat hubungan positif antara manajemen stres dengan kualitas hidup pada lanjut usia. Lanjut usia yang memiliki manajemen stres yang baik maka akan memiliki kualitas hidup yang baik pula, dan sebaliknya lanjut usia yang memiliki manajemen stres yang kurang baik maka akan berimbas pada menurunnya kualitas hidup. Dengan demikian, dapat dikatakan bahwa manajemen stres berperan penting dalam meningkatkan kualitas hidup lanjut usia, karena lanjut usia yang memiliki manajemen stres yang tinggi akan memiliki keterampilan yang baik dalam mengidentifikasi gejala stres, menganalisa gejala stres, strategi terhindar dari stres serta mengembangkan coping stress.

Hasil penelitian menunjukkan bahwa tidak ada hubungan antara dukungan sosial dengan kualitas hidup. Menurut Jiang, Drolet dan Kim (2018) dukungan sosial yang diberikan pada lanjut usia memiliki kompleksitas lebih tinggi dibandingkan dengan individu yang berada pada usia di bawahnya karena lanjut usia cenderung akan melihat dukungan sosial dari sisi keuntungan maupun kerugian. Lanjut usia dapat mempersepsi dukungan sosial sebagai bentuk beban sosial terhadap orang di sekitarnya. Hal ini berbeda dengan usia dewasa muda yang cenderung fokus pada sisi positif dari dukungan sosial.

Liang, Krause dan Bennet (2001) menyatakan bahwa banyak lanjut usia yang mengagungkan kemandirian sampai-sampai tidak ingin mendapatkan bantuan dari orangorang terdekatnya kecuali jika lanjut usia tersebut merasa akan dapat membalas bantuan tersebut. Bila sifat ini muncul secara berlebihan atau lanjut usia tersebut merasa tidak mampu untuk membalas bantuan yang diberikan oleh orang lain, maka bantuan yang diberikan oleh orang lain justru akan dapat memicu tekanan psikologis pada lanjut usia. Kondisi tersebut menyebabkan saat orang-orang di sekitar akan memberikan bantuan atau dukungan sosial pada lansia, maka perlu mempertimbangkan jenis bantuan yang akan diberikan, apakah bantuan tersebut akan dikehendaki atau tidak oleh lanjut usia yang menerimanya dan seperti apa efek dari pemberian bantuan tersebut pada lanjut usia yang bersangkutan. Bantuan yang efektif sifatnya dapat menghemat tenaga bagi para lanjut usia sehingga akan mampu menumbuhkan kepuasan dalam diri lanjut usia yang bersangkutan serta dampaknya akan mengarah pada pertumbuhan dan meningkatkan kualitas hidup dari para lanjut usia.

Lanjut usia yang menjadi subjek dalam penelitian ini mayoritas berusia antara 60-64 tahun sehingga masih berada pada masa lansia awal dan masih memiliki kondisi fisik dan psikis yang masih baik. Kondisi tersebut menyebabkan belum terjadinya penurunan yang drastis dalam fungsi fisik, kognitif, penurunan fungsi dan potensi seksual, serta perubahan aspek psikososial sehingga mayoritas sampel penelitian belum terlalu membutuhkan dukungan sosial dari orang lain. Kondisi tersebut akan berbeda pada lanjut usia yang sudah memasuki usia 70 tahun ke atas yang sudah mengalami banyak penurunan terhadap kondisi 
fisiknya. Menurut Sarafino (2011) lanjut usia akan lebih banyak menerima dukungan sosial setelah mengalami kejadian yang membuat stres daripada saat tidak mengalami stres. Hal ini sesuai dengan hasil penelitian yang menunjukkan bahwa sebagian besar sampel penelitian, yaitu sebesar $62,5 \%$ memiliki tingkat manajemen stres dalam kategori sedang sehingga diasumsikan sudah mampu mengantisipasi, mencegah, mengelola, dan memulihkan diri dari stres yang dirasakan dan sebagai dampaknya tidak terlalu membutuhkan dukungan sosial dari orang-orang di sekitarnya.

Hasil penelitian ini menunjukkan bahwa faktor internal (manajemen stres) lebih berperan daripada faktor eksternal (dukungan sosial) terhadap kualitas hidup pada lanjut usia. Apabila dukungan sosial diberikan pada lanjut usia yang memiliki manajemen stress yang tinggi, maka dukungan sosial tersebut efektif untuk meningkatkan kualitas hidup pada lanjut usia, namun apabila dukungan sosial tersebut diberikan pada lanjut usia yang memiliki manajemen stress yang rendah, maka akan kurang berperan dalam meningkatkan kualitas hidup pada lanjut usia. Hal tersebut dapat terlihat dari hasil penelitian ini yang menunjukkan bahwa variabel yang berpengaruh terhadap kualitas hidup adalah manajemen stres dan bukan dukungan sosial, sehingga dukungan sosial tidak akan memberikan dampak yang positif bagi peningkatan kualitas hidup apabila tidak disertai dengan manajemen stres yang tinggi.

Penelitian ini masih memiliki keterbatasan yaitu pada alat ukur WHOQOL-BREF. Artinya, alat ukur ini sebaiknya dikaji ulang berkaitan dengan penerjemahan ke dalam Bahasa Indonesia. Mengingat beberapa sampel penelitian memberi komentar bahwa terdapat katakata dan bahasa yang tidak umum digunakan, sehingga membutuhkan waktu untuk dapat memahami pernyataan yang terdapat di dalam alat ukur tersebut.

\section{Simpulan}

Hasil penelitian ini menyimpulkan bahwa ada hubungan yang sangat signifikan antara manajemen stres dan dukungan sosial dengan kualitas hidup pada lanjut usia. Manajemen stres dan dukungan sosial secara bersama-sama dapat berpengaruh kepada kualitas hidup lanjut usia. Selanjutnya ada hubungan positif yang sangat signifikan antara manajemen stres dengan kualitas hidup lanjut usia. Semakin baik manajemen stres maka akan semakin tinggi kualitas hidup lanjut usia, dan sebaliknya semakin kurang baik manajemen stres maka akan semakin rendah kualitas hidup lanjut usia. Sementara itu, hasil penelitian ini juga menunjukan bahwa tidak ada hubungan antara dukungan sosial dengan kualitas hidup lanjut usia.

\section{DAFTAR PUSTAKA}

Badan Kependudukan dan Keluarga Berencana Nasional. (2013). Lansia siapa bilang sia-sia. Jakarta: Direktorat Kerjasama Pendidikan Kependudukan BKKBN.

Berk, L. E. (2017). Development through the lifespan (7th ed.). Pearson.

Boyd, M.A., \& Nihart, M.A. (2005). Psychiatric nursing contemporary practice. USA: Lippincontt Raven Publisher.

Chang, P. J., Wray, L., \& Lin, Y. (2014). Social relationships, leisure activity, and health in older adults. Health Psychology, 33(6), 516-523.

Feeney, B. C., \& Collins, N. L. (2015). Thriving through relationships. Current Opinion in Psychology, 1, 22-28. https://doi.org/10.1016/j.copsyc.2014.11.001.

Gatz, M., Kasl-Godley, J.E. \& Karel, M.J. (1996) Aging and mental disorder. In K.W. Schaie \& J.E. Birrend (Eds), Handbook of the psychology of aging (4th ed) San Diego, CA: Academic Press. 
Hurlock, E.B. (2013). Psikologi perkembangan. Penerjemah: Istiwidayanti dan Soedjarwo. Jakarta: Erlangga.

Jiang, L., Drolet, A., \& Kim, H. S. (2018). Age and social support seeking: Understanding the role of perceived social costs to others. Personality and Social Psychology Bulletin, 44(7), 1104-1116. https://doi.org/10.1177/0146167218760798.

Kementrian Kesehatan RI. (2017). Analisis lansia di Indonesia. Jakarta: Pusat Data dan Informasi Kemenkes RI.

Liang, J., Krause.N.M., \& Bennet, J.M. (2001). Social exchange and well-being: Is giving better than receiving? Psychology and aging, 16. 511-523.

Putri, S.T., Fitriana, L.A., Ningrum, A., \& Sulastri, A. (2015). Studi komparatif: Kualitas hidup lansia yang tinggal bersama keluarga dan panti. Jurnal Pendidikan Keperawatan Indonesia, 1(1) (2015).

Raeburn, J.M., \& Rootman, I. (1988). Towards an expanded health field concept: conceptual and research issues in a new era of health promotion. Health promotion international, 3(4), 383-392.

Rasmun. (2004). Stress, koping, dan adaptasi. Jakarta: Sagung Seto.

Robbins, S.P., \& Coulter, M. (2004). Manajemen jilid 1. Jakarta: Indeks.

Sarafino, E.P. (2011). Health psychology: Biopsychosocial interactions. Seventh edition. USA: John Wiley \& Sons.

Sari, H., \& Yuslia, C. (2013). Hubungan manajemen stres dengan kualitas hidup lansia di gampong peuniti banda aceh. Idea Nursing Journal, IV(2), 68-79. Diunduh 27 Oktober 2017, dari www.jurnal.unsyiah.ac.id/INJ/article/view/1565.

Smith, C.J. (2002). Stress management: A comprehensive handbook of techniques and strategies. New York: Springer Publishing Company, Inc.

Tamara, E., Bayhakki., \& Nauli, F.A. (2014). Hubungan antara dukungan keluarga dan kualitas hidup pasien diabetes mellitus tipe II di RSUD Arifin Achmad Provinsi Riau. JOM PSIK, 1(2) Oktober 2014. Diakses 03 September 2018, dari https://media.neliti.com/ media/publications/188308-ID-hubungan-antara-dukungan-keluarga-dan-ku.pdf.

The WHOQOL Group. (1998). Development of the world health organization WHOQOL-BREF quality of life assessment. Psychological Medicine, 28. 551-558. United Kingdom Cambridge University Press.

Uchino, B.N. (2004). Social support and physical health: Understanding the health consequences of relationship. Yale University Press.

Undang-Undang Republik Indonesia. (1998). Undang-Undang No. 13 Tahun 1998 tentang kesejahteraan lanjut usia. Lembaran negara RI Tahun 1998, Nomor 190. Sekretariat Negara. Jakarta.

United Nations Department of Economic and Social Affairs. (2017). World population prospects: The 2017 revision. Diakses dari https://www.un.org/development/desa/ publications/world-population-prospects-the-2017-revision.html.

Vaarama, M., Pieper, R., \& Sixsmith, A. (2008). Care-realted quality of life in old age: Concepts, models, and empirical findings. New York: Springer Publishing Company, Inc.

Walikota Yogyakarta. (2019). Keputusan wali kota Yogyakarta Nomor 450 tahun 2019 tentang roadmap kota Yogyakarta menuju kota ramah lanjut usia. https://hukum. jogjakota.go.id. 